\title{
Teknologi Instalasi Pengolah Air Limbah (IPAL) Berbasis Pembangkit Photovoltaic (PV) untuk Proses Produksi Batik-Tulis Tanjung Bumi yang Ramah Lingkungan
}

\author{
Amirullah \\ Universitas Bhayangkara Surabaya
}

\author{
Tri Wardoyo \\ Universitas Bhayangkara Surabaya
}

\author{
Achmad Yulianto \\ Universitas Bhayangkara Surabaya
}

\author{
Anis Fitriani \\ Universitas Bhayangkara Surabaya
}

Uais Sabilah Muhammad

\begin{abstract}
Partners of Technology Products Disseminated to the Community or Produk Teknologi yang Didesiminasikan ke Masyarakat (PTDM) are Micro, Small, and Medium Busines or Usaha Mikro Kecil dan Menengah (UMKM) Zulpah Batik Madura (Partner 1) and the Home Batik Group, Material Supplier, and Tailor in Dusun Kramat (Partner 2). There are two problems in terms of production aspects. After the batik production process, especially those that use chemicals, Partner 1 craftsmen usually immediately dispose of wastewater into the nearest ditch or river without going through the previous waste treatment process. The area of Paseseh Village, Tanjung Bumi District as the location of Partners 1 and 2 often experiences power outages during peak load periods at night. The impact is that the disposal of batik waste by Partner 1 directly into the environment can pollute the surrounding environment, namely water and soil. The pump of partner 1 does not work so that it interferes with the waste treatment process and Partner 2 can not carry out batik activities, thereby reducing handmade batik products. The program aims to improve the quality and quantity of environmentally friendly Tanjung Bumi handmade batik in Paseseh Village, Tanjung Bumi District, Bangkalan Regency. The activity method is taken through the implementation of two activities. The first activity is the application of appropriate technology for the wastewater treatment plant or Instalasi Pengolah Air Limbah (IPAL) residues of the handmade batik production process of Partners 1. The second activity is the application of the Solar Home System (SHS) technology to Partner 1 using a household-scale PV generator of Partner 1. The handmade batik IPAL building consists of three wax catcher tanks, three settling tanks and flow rates, a coagulation tank containing an alum filter, three activated carbon adsorption tanks containing wood charcoal or coconut shell filters, and a final control tank. The final control tank serves to accommodate the last wastewater which is relatively safe for the environment before being discharged into sewers or rivers. The wastewater can also be used for the process of washing handmade batik again or used for watering plants. A PV generator system with a $900 \mathrm{Wp}$ panel power, $12 \mathrm{~V} / 100$ Ah battery, and a 1,000 Whybrid inverter is used to drive a $200 \mathrm{~W}$ pump to lift wastewater from the settling basin and water leveller to the coagulation tank. This renewable energy-based power source is also used for $150 \mathrm{~W}$ lighting and $150 \mathrm{~W}$ power source for electric batik canting for Partners 1 and 2 in both offgrid and on-grid modes.
\end{abstract}

Keywords: Handmade Batik; Madura; PV Generator; Tanjung Bumi; Wastewater Treatment Plant

\section{Abstrak}

Mitra Produk Teknologi yang Didesiminasikan ke Masyarakat (PTDM) adalah UMKM Zulpah Batik Madura (Mitra 1) dan Kelompok Pembatik Rumahan, Pemasok Bahan, dan Penjahit Dusun Kramat (Mitra 2). Permasalahan ditinjau dari aspek produksi ada dua. Pasca proses produksi batik-tulis khususnya yang menggunakan bahan-bahan kimia, pengrajin Mitra 1 biasanya langsung membuang air limbah begitu saja ke selokan atau sungai terdekat tanpa melalui proses pengolahan limbah sebelumnya. Wilayah Desa Paseseh Kecamatan Tanjung Bumi sebagai lokasi Mitra 1 dan 2 sering mangalami pemadaman listrik ketika periode beban puncak pada malam hari. Dampaknya pembuangan limbah batik oleh Mitra 1 langsung ke lingkungan dapat mencemari lingkungan sekitarnya yaitu air dan tanah. Pompa IPAL Mitra 1 tidak berfungsi sehingga mengganggu proses pengolahan limbah. Mitra 2 tidak dapat melakukan aktivitas membatik sehingga menurunkan produk batik-tulis. Tujuan program adalah meningkatkan kualitas dan kuantitas batik-tulis Tanjung Bumi yang ramah lingkungan di Desa Paseseh Kecamatan Tanjung Bumi Kabupaten Bangkalan. Metode kegiatan ditempuh melalui implementasi dua kegiatan. Kegiatan 
pertama penerapan Teknologi Tepat Guna instalasi pengolah air limbah (IPAL) residu proses produksi batik tulis ke Mitra 1. Kegiatan kedua adalah penerapan Teknologi Tepat Guna (TTG) Solar Home System (SHS) ke Mitra 1 menggunakan pembangkit PV skala rumah tangga. Bangunan IPAL Batik-Tulis terdiri dari bak penangkap lilin, bak pengendap dan perata aliran berjumlah tiga buah, bak koagulasi berisi filter tawas, bak absorbsi karbon aktif berisi filter arang kayu atau batok kelapa berjumlah tiga buah, dan bak kontrol akhir. Bak kontrol akhir berfungsi menampung air limbah terakhir yang relatif aman bagi lingkungan sebelum dibuang ke saluran selokan atau sungai. Air limbah juga dapat dimanfaatkan untuk proses pencucian batik kembali atau dipakai untuk menyiram tanaman. Sistem pembangkit PV dengan daya panel $900 \mathrm{Wp}$, baterai $12 \mathrm{~V} / 100 \mathrm{Ah}$, dan inverter hybrid $1000 \mathrm{~W}$ dipakai menggerakkan pompa $200 \mathrm{~W}$ untuk mengangkat air limbah dari bak pengendap dan perata aliran ke bak koagulasi. Sumber listrik berbasis energi terbarukan ini juga digunakan untuk lampu penerangan $150 \mathrm{~W}$ dan sumber daya canting batik elektrik $150 \mathrm{~W}$ bagi Mitra 1 dan 2 baik pada mode off-grid maupun mode on-grid.

Kata kunci: Batik-Tulis; IPAL; Madura; Pembangkit PV; Tanjung Bumi

\section{Pendahuluan}

Tanjung Bumi dikenal sebagai salah satu menjadi kecamatan di Kabupaten Bangkalan yang memproduksi batik, sehingga popularitasnya sangat dikenal oleh penggemar batik di tanah air. Hingga sekarang di wilayah ini ada 530 unit usaha batik dengan 1.000 lebih pengrajin. Jumlah tersebut belum termasuk para pengrajin yang mengerjakan secara perorangan yang bersifat kerajinan tangan saja. Usaha kecil menengah batik tersebut tersebar di Desa Paseseh, Desa Macajah, Desa Telaga Biru, dan Desa Bumi Anyar. Tempo dulu membatik menghabiskan waktu berbulan-bulan, bahkan khusus batik-tulis gentongan prosesnya bisa mencapai setahun, hanya untuk sepotong batik karena pembuatan motif yang sangat rumit dan detil. Proses tersebut merupakan sesuatu luar biasa dan benar-benar sebuah mahakarya, sehingga sangat wajar jika harga jualnya bisa menembus nominal Rp5 juta untuk sepotong kain batik tulis. Ciri khas lain yang mengemuka dari batik Tanjung Bumi adalah seluruh proses pembuatannya $100 \%$ menggunakan tangan-tangan pengrajin (handmade), bukan melalui proses cap maupun printing (Radar Madura Jawa-Pos, 2015).

Dusun Kramat Desa Paseseh merupakan salah satu sentra pembuatan dan usaha batik-tulis di Kecamatan Tanjung Bumi Bangkalan. Kecamatan ini terletak kurang lebih $80 \mathrm{~km}$ lebih dari Surabaya dan dapat ditempuh melalui Jembatan Suramadu dengan waktu sekitar 1,5 jam dengan rute berturut-turut mulai dari pertigaan Desa Tengkel (Kecamatan Burneh), Kota Bangkalan, Kecamatan Arosbaya, Kecamatan Klampis, Kecamatan Sepulu, dan Kecamatan Tanjung Bumi. Alternatif menuju Kecamatan Tanjung Bumi juga bisa ditempuh melalui perjalanan laut menggunakan penyeberangan (kapal feri) dari Pelabuhan Ujung Surabaya menuju Kamal selama kurang lebih 45 menit dan dilanjutkan dengan perjalanan darat sekitar 2 jam. Gambar 1 menunjukkan peta detail lokasi mitra Program Teknologi yang Didiseminasi ke Masyarakat (PTDM) di Dusun Kramat Desa Paseseh Kecamatan Tanjung Bumi Bangkalan.

Kegiatan PTDM Tahun 2021 menggandeng Usaha Mikro Kecil Menengah (UMKM) Zulpah Batik Madura sebagai Mitra 1. UMKM berlokasi di Dusun Kramat Desa Paseseh Kecamatan Tanjung Bumi dan dipimpin oleh Wurrotul Muhajjalah atau Ibu Wuri. Perempuan ini membuka usaha batik tulis Zulpah sebagai bagian konsistensi untuk mewujudkan kecintaannya terhadap seni budaya warisan leluhur Madura dan melanjutkan usaha kerajinan yang telah dirintis serta sudah dikembangkan secara turun temurun oleh kedua orang-tuanya (Bapak dan Ibu Zulpah). Usaha batik tulis secara konsisten menggunakan teknik pembuatan dan motif Batik Gentongan Tanjung Bumi dengan ciri khas warna lugas, tegas, menyolok, berani (colourful), dan memiliki aroma rempah-rempah karena perendaman. Motif tersebut antara-lain motif kembang randu, burung hong, sek melaya, ola'-ola' dan sejumlah motif lainnya. Produk batik-tulis usaha ini antara-lain kain batik-tulis tunggal (per-potong), batik sarimbit (untuk pasangan suami-istri), taplak meja, samper atau kain batik panjang (Bahasa Jawa: sewek), dan batik-tulis selendang lebar/panjang (pasmina). 


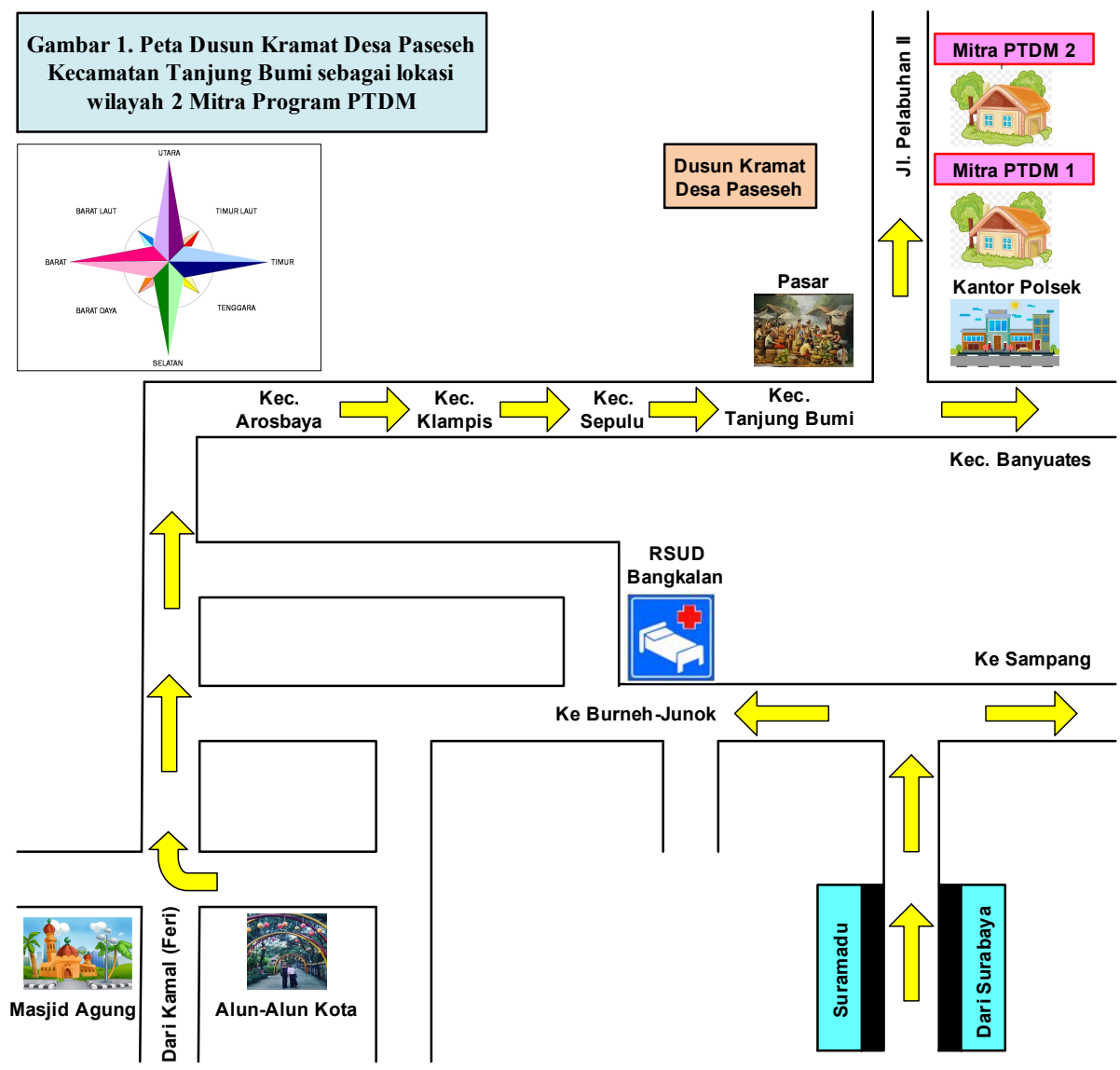

Gambar 1. Peta detail lokasi mitra di Dusun Kramat Desa Paseseh Kecamatan Tanjung Bumi

Untuk menjalankan proses melukis diatas batik (membatik), UMKM Zulpah Batik Madura dibantu oleh pembatik berjumlah sekitar 200 orang dengan spesialisasi tugas antara lain: membentuk pola (rengreng), membuat motif kecil (kurik), mengisi motif (essean), menutup motif yang tidak ingin diwarnai (nebbeng). Mayoritas pembatik adalah para ibu rumah-tangga di sekitar Dusun Kramat Desa Paseseh yang dibayar dengan upah sistem borongan berdasarkan spesialiasasi tugas, waktu, dan tingkat kerumitan motif batik tulis yang dikerjakan oleh pembatik. Pembatik ibu rumah-tangga ini selanjutnya dikenal dengan pembatik rumahan. Untuk suplai bahan pembuatan batik-tulis (kain mori, lilin, dan bahan pewarna), UMKM dibantu oleh para pemasok bahan dari Desa Paseseh atau desa tetangga di Kecamatan Tanjung Bumi. Pembatik rumahan dan pemasok bahan pewarnaan alam tersebut, tergabung dalam Paguyuban atau Kelompok pembatik rumahan dan pemasok bahan batik-tulis di Desa Paseseh. Anggota kelompok selanjutnya berkembang termasuk di dalamnya penjahit baju batik karena semenjak pendemi COVID-19, Mitra 1 tidak hanya menjual kain batik tetapi juga menjual baju potong berbahan kain batik-tulis Tanjung Bumi. Pimpinan kelompok adalah Ali Mortono, S.Psi. (dipanggil Pak Alim Hafidz) merupakan warga pendatang asal Sampang, lama menetap dan bermukim sama di Dusun Kramat, Desa Paseseh. Program PTDM Tahun 2021 juga menggandeng kelompok pembatik rumahan, pemasok bahan, dan penjahit di Desa Paseseh sebagai Mitra 2. Gambar 2 menunjukkan profil usaha UMKM Zulpah Batik Madura sebagai Mitra 1.

Pada proses produksi batik-tulis, salah satu dampak negatif yang dihasikan oleh UMKM batik adalah hasil residu khususnya limbah cair. Limbah cair batik yang dibuang umumnya berasal dari proses pewarnaan, pencucian dan pelepasan malam (pelorodan). Limbah tersebut umumnya mengandung zat-zat pencemar yang kadarnya melebihi baku mutu (Lilin Indrayani, 2019). Survei lapangan pengusul ke lokasi menunjukkan hampir pada semua UMKM batik-tulis di Kecamatan Tanjung Bumi termasuk UMKM Zulpah Batik Madura (Mitra 1) tidak mempunyai 
instalasi pengolahan limbah batik. Pasca proses pelorodan kain batik-tulis yang menggunakan mayoritas menggunakan bahan-bahan kimia, pengrajin biasanya langsung membuang air limbah ke selokan atau sungai terdekat. Padahal pembuangan limbah batik langsung ke lingkungan tanpa proses pengolahan limbah terlebih dahulu, niscaya dapat mencemari lingkungan sekitarnya yaitu air dan tanah. Untuk mengatasi masalah Program PTDM mengajukan kegiatan penerapan Teknologi Tepat Guna (TTG) instalasi pengolah air limbah (IPAL) residu proses produksi batik-tulis kepada Mitra 1 .

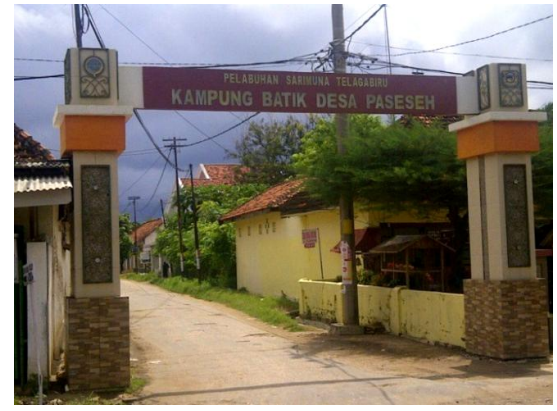

(a)

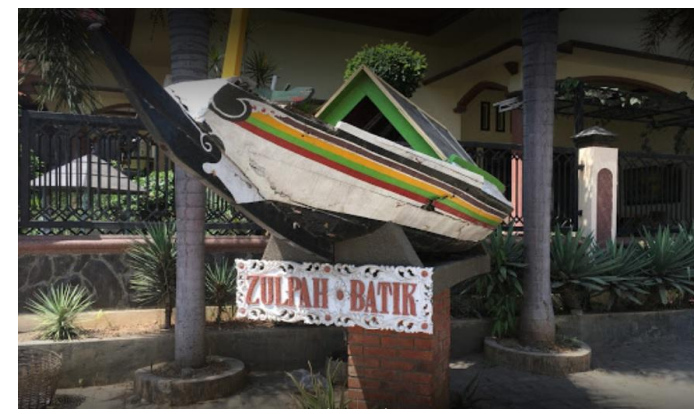

(c)

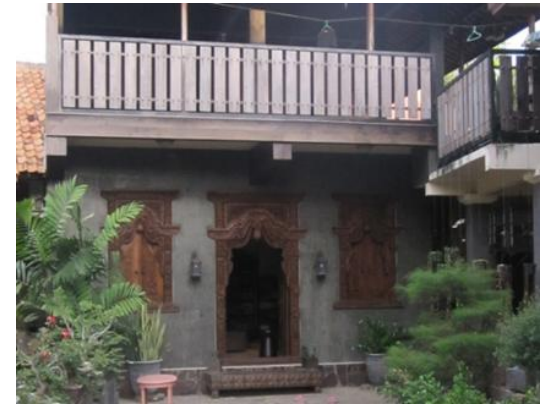

(b)

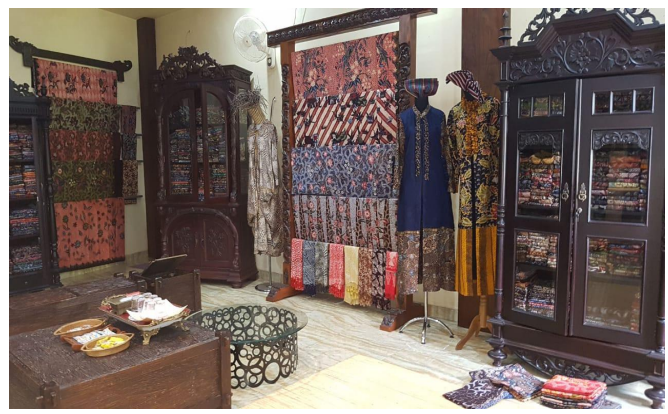

(d)

Gambar 2. Profil usaha mitra (a) Dusun Kramat, Desa Paseseh, Kecamatan Tanjung Bumi, (b) UMKM Zulpah Batik Madura (Mitra 1), (c) Miniatur Perahu Sarimuna Mitra 1, (d) Galeri Batik-Tulis Mitra 1

Kecamatan Tanjung Bumi merupakan salah satu wilayah pesisir utara di Kabupaten Bangkalan selain Kecamatan Arosbaya, Klampis, dan Sepulu. Permasalahan yang selalu terjadi secara berulang di sejumlah wilayah utara adalah gangguan pemadaman listrik (Anonim, 2018). Permasalahan dipicu karena pelanggan listrik wilayah utara letaknya jauh dari gardu induk (GI) Gili Timur Kecamatan Kamal dan GI Bangkalan Kecamatan Burneh yang keduanya beroperasi di pesisir selatan Kabupaten Bangkalan. Total dua GI tersebut berkapasitas 150 mega-volt Ampere (MVA) dan melayani pelanggan listrik seluruh kabupaten sebesar 80 MVA hingga 90 MVA. Jauhnya pelanggan listrik di Tanjung Bumi (di wilayah utara) dari GI (di wilayah selatan) menyebabkan tegangan jatuh (drop) yang relatif tinggi sehingga tegangan pada sisi pelanggan selatan turun dan pada kondisi tertentu memaksa PLN melakukan pemadaman listrik khususnya pada beban puncak (jam 17.00-22.00 WIB). Disisi lain, pada IPAL batik-tulis terdapat bak pengendap dan perata limbah yang pada tahap pengolahannya harus dinaikkan ke bak koagulasi menggunakan pompa yang disuplai oleh listrik PLN. Kondisi lainnya adalah mayoritas pembatik rumahan di bawah koordinasi Kelompok Pembatik Rumahan Dusun Kramat (Mitra 2) umumnya melakukan aktivitas membatik (membuat pola penggunakan canting batik) pada malam hari. Frekuensi dan durasi pemadaman listrik lama di wilayah Dusun Kramat menyebabkan mereka tidak dapat melakukan aktivitas membatik sehingga menurunkan produk hasil batik tulis. Berpijak pada kendala ini maka program PTDM mengusulkan penerapan TTG Pembangkit PV ke Mitra 1 menggunakan pembangkit PV skala rumah tangga untuk suplai daya listrik pada pompa untuk menaikkan air limbah dari bak pengendap dan perata aliran ke bak koagulasi. Mitra 2 tetap 
bisa melakukan aktivitas membatik walaupun listrik PLN di Desa Paseseh mengalami pemadaman..

\section{Metode Pelaksanaan}

Permasalahan mitra sudah dibahas secara detail pada Bab 1. Selanjutnya berdasarkan permasalahan di lapangan dan kesepakatan antara pelaksana dengan kedua mitra, program PTDM menawarkan metode kegiatan untuk menyelesaikan permasalahan di lapangan. Metode pertama adalah penerapan Teknologi Tepat Guna (TTG) instalasi pengolah air limbah (IPAL) residu proses produksi batik-tulis ke Mitra 1. Tujuan kegiatan adalah supaya residu cair bekas pengolahan produksi batik (air bekas rendaman, air bekas cucian, dan air bekas pewarnaan) yang umumnya menggunakan bahan-bahan kimia, terlebih dahulu ditampung dan diolah pada IPAL agar mencapai kadar aman, sebelum dibuang oleh pengrajin Mitra 1 ke lingkungan sekitar misalnya ke selokan selokan atau sungai terdekat. Metode kedua adalah penerapan TTG Solar Home System (SHS) ke Mitra 1 menggunakan pembangkit Photovoltaic (PV) stand-alone (mandiri) skala rumah tangga. Perangkat pembangkit PV yang dipasang di Mitra 1 antara-lain: Panel PV $900 \mathrm{Wp}$, Battery Energy Storage (BES), Hybrid Inverter 1000 W (MPPT Solar Charge Controller, Inverter Pure Sin, dan Grid), 10 buah titik lampu, 2 stop kontak, dan kabel instalasi. Penerapan teknologi pembangkit PV bertujuan: (a) Menggerakkan pompa untuk menaikkan air limbah dari bak pengendap dan perata aliran menuju bak koagulasi, dan (b) Aktivitas membatik masih bisa dilakukan oleh Mitra 2 walaupun pasokan listrik PLN di Desa Paseseh mengalami gangguan akibat pemadaman. Solusi tersebut menjadi alternatif karena Desa Paseseh berada di wilayah Kecamatan Tanjung-Bumi berlokasi di wilayah utara, relatif tentan mengalami gangguan pemadaman listrik akibat jauhnya pelanggan dari Gardu Induk $150 \mathrm{kV}$ Burneh Bangkalan berlokasi di wilayah selatan sejauh hampir $60 \mathrm{~km}$.

Perencanaan sistem pembangkit PV mode off-grid untuk mendapatkan desain PV optimal dijelaskan sesuai tahapan berikut (Azhar Kamal, 2017): (1) Langkah pertama menentukan tegangan total dan arus total keluaran Panel PV sesuai Persamaan 1 dan 2.

Tegangan Total Panel PV = Jumlah Modul PV $\times$ Tegangan Modul PV Hubung Terbuka (Voc)

Arus Total Panel PV = Arus Modul PV Hubung Singkat (Isc)

(2) Langkah kedua ialah menghitung kebutuhan energi masing-masing peralatan sesuai Persamaan 3.

$$
\text { Energi Harian = Daya }(W) \times \text { Waktu (jam) }
$$

Berdasarkan akumulasi jumlah energi harian peralatan listrik, selanjutnya ditentukan daya panel PV yang dibutuhkan sesuai Persamaan 4.

Daya Panel PV yang dibutuhkan = Energi Harian $(W h) / J u m l a h$ jam efektif

Nilai Jumlah jam efektif panel surya diambil sebesar 4 jam. (3) Langkah ketiga yakni menghitung jumlah kebutuhan baterai berdasarkan jumlah konsumsi energi harian sesuai Persamaan 5.

Kapasitas Baterai = Energi Harian (Wh) / Nilai DoD

Nilai Depth of Discharge ( $D o D$ ) adalah jumlah muatan atau energi yang dikeluarkan atau dipakai dari baterai. DoD dinyatakan dengan persentase dari kapasitas nominal baterai (Rafael Sianipar, 2014). (4) Langkah keempat adalah menentukan durasi pemanfaatan pembangkit PV berdasarkan nilai investasi atau break even point (BEP) dengan prosedur: (a) Energi listrik yang dihasilkan dari instalasi pembangkit PV sesuai Persamaan 6.

Energi Listrik Harian yang Dihasilkan = Kapasitas Panel Surya Terpasang / Jumlah Jam Efektif

dengan Energi Listrik Harian yang Dihasilkan berupa jumlah kWh/hari; (b) Menentukan tarif listrik sesuai Persamaan 7. 
Tarif Listrik = Jumlah $\mathrm{kWh} /$ hari $\times$ Jumlah Jam Efektif

Akhirnya, diperoleh durasi pemanfaatan sistem pembangkit PV berdasarkan nilai investasi atau break even point (BEP) sesuai Persamaan 8.

Waktu BEP = Biaya Investasi PLTS / Tarif Listrik

\section{Hasil dan Pembahasan}

\subsection{Kunjungan Pendahuluan ke Mitra}

Untuk memastikan bahwa kegiatan PTDM yang dilaksanakan berjalan sesuai dengan rencana, dibutuhkan koordinasi persiapan antara pelaksana dengan Mitra 1 dan Mitra 2. Kegiatan dilaksanakan oleh anggota pelaksana dan pimpinan mitra pada lokasi UMKM di Dusun Kramat Desa Paseseh Kecamatan Tanjung Bumi hari Sabtu, 26 Agustus 2021. Kegiatan persiapan meliputi: (a) Melakukan sosialisasi tentang rencana kegiatan antara tim pelaksana dengan kedua Mitra, (b) Menentukan jadwal pelaksanaan kegiatan yang telah disepakati bersama antara Tim Pelaksana dengan kedua Mitra, (c) Menentukan dan mendiskusikan jenis partisipasi mitra untuk mendukung semua program kegiatan yang telah direncanakan oleh Tim Pelaksana.

Pertisipasi mitra pada pelaksanaan program PTDM meliputi: (a) Mitra 1 memfasilitasi dan menyediakan tempat bagi pelaksanaan kegiatan pelatihan, praktek, dan pendampingan seluruh kegiatan PTDM, (b) Mitra 2 melakukan sosialisasi dan mobilisasi kepada anggota kedua mitra supaya mereka mengikuti semua kegiatan pelatihan, praktek, dan pendampingan PTDM, (c) Mitra 1 dan Mitra 2 memfasilitasi pembentukan panitia pelaksana terdiri dari tim pelaksana dan mitra PTDM serta bertugas memberikan pengarahan dan informasi kepada anggota/pekerja Mitra tentang penyelenggaraan kegiatan PTDM, (d) Mitra 1 memfasilitasi dan memberikan masukan kepada narasumber untuk menyukseskan kegiatan sesuai dengan target luaran setiap kegiatan PTDM, (e) Mitra 1 membantu menyiapkan kebutuhan pendukung kegiatan pelatihan, praktek, dan pendampingan meliputi; spanduk; makalah dan materi pelatihan, penyediaan koneksi listrik dan internet, meja-kursi, pengeras suara (sound system), dan layar LCD proyektor, dan (f) Mitra 2 membantu melakukan koordinasi kegiatan PTDM kepada anggota/pekerja Mitra mengenai jadwal yang sudah ditentukan dan disepakati dengan panitia pelaksana PTDM. Kegiatan selama kunjungan pendahuluan meliputi diskusi permasalahan mitra, dampak dari permasalahan yang muncul, solusi yang ditawarkan tim pelaksana program, metode kegiatan, dan target luaran program PTDM. Gambar 3 menunjukkan koordinasi persiapan kegiatan pelaksana dengan Mitra.
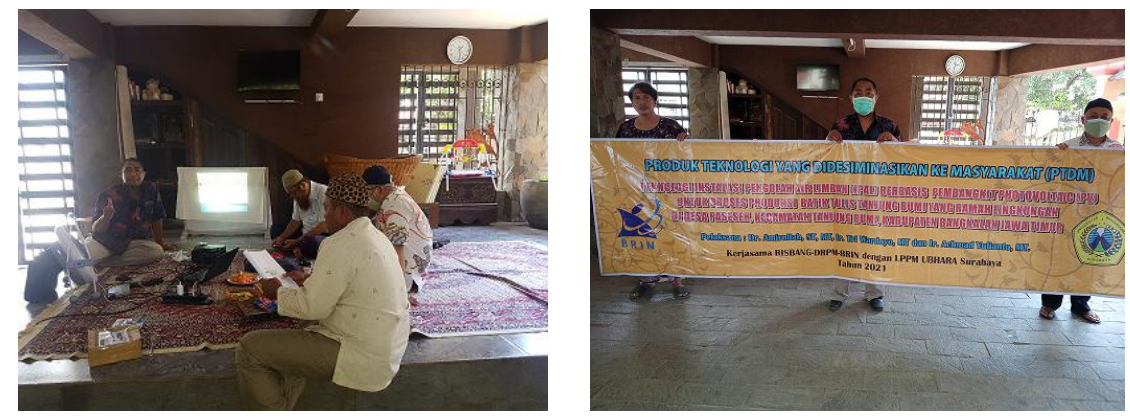

Gambar 3. Koordinasi persiapan kegiatan antara pelaksana dengan mitra

\subsection{Penerapan Teknologi IPAL Batik Tulis}

Gambar 4 menunjukkan lima bagian bangunan IPAL yaitu (1) Bak penangkap lilin, (2) Bak pengendap dan perata aliran berjumlah tiga buah, (3) Bak koagulasi berisi filter tawas, (4) Bak absorbsi karbon aktif berisi filter arang kayu atau batok kelapa berjumlah tiga buah, dan (5) bak kontrol akhir. Pekerjaan bangunan IPAL Batik Tulis di Mitra 1 dikerjakan sejak 1 s.d. 30 September 2021. Jika mengacu pada desain Standar Balai Besar Kerajinan Batik (BBKB) 
Yokyakarta ada 2 buah bak yang prosesnya diabaikan dan diganti menjadi Bak Absorbsi yaitu Bak Proses Biologi atau Bak anaerobic filter. Proses filter limbah pada kedua bak tersebut menggunakan bola-bola plastik yang pada permukaannya ditumbuhi bakteri. Saat air limbah mengalir pada filter, bakteri-bakteri tersebut menguraikan zat-zat dalam limbah (Abdul Hoyyi, 2018). Kendalanya adalah pelaksana dan mitra tidak kesulitan mendapatkan bakteri anaerobic filter yang dibutuhkan di Tanjung Bumi. Disisi lain arang kayu atau arang batok kelapa untuk pengisi filter di Bak absorbsi relatif mudah diperoleh dengan harga terjangkau. Gambar 4 menunjukkan desain IPAL batik-tulis berbasis pembangkit photovoltaic (PV).

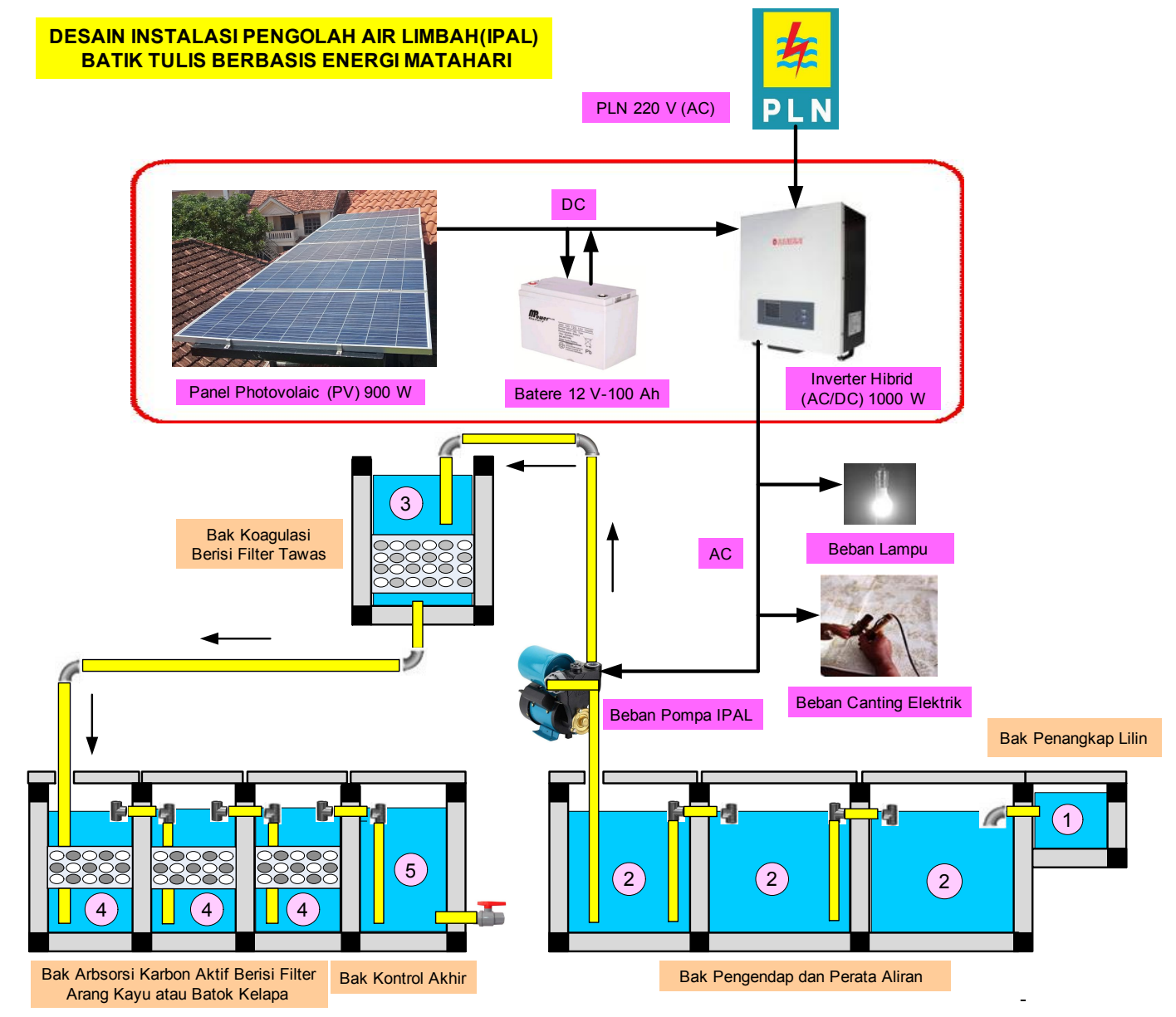

Gambar 4. Desain IPAL batik-tulis berbasis pembangkit PV

Mitra 1 sebelumnya sudah mempunyai bak penangkap lilin (Bak 1). Pelaksana kegiatan dibantu Mitra 1 selanjutnya mengerjakan pekerjaan fisik bangunan Bak 2 sampai dengan Bak 5. Gambar 4 bagian Bak 2 menunjukkan desain tiga buah bak pengendap dan perata aliran (tampak samping). Bak ini berada di dalam tanah dengan panjang total bak adalah $275 \mathrm{~cm}$, lebar $140 \mathrm{~cm}$, dan dalam $120 \mathrm{~cm}$ sehingga diperoleh volume total sebesar 4,62 $\mathrm{m}^{3}$. Panjang ketiga bak dari kanan masing-masing $100 \mathrm{~cm}, 100 \mathrm{~cm}$, dan $75 \mathrm{~cm}$. Bak pengendap berfungsi untuk meratakan volume dan karakteristik limbah dan mengendapkan padatan besar dalam limbah. Bak ini juga berfungsi sebagai bak tandon. Bila sudah penuh, air limbah dalam bak ini baru dipompa masuk ke bak pengolahan kimia. Gambar 5 menunjukkan tahapan pekerjaan bangunan bak pengendap dan perata. 


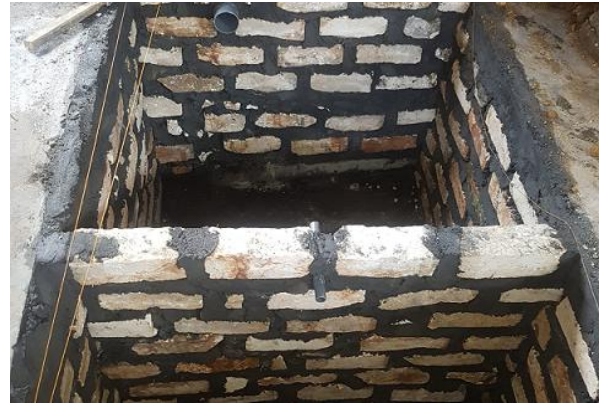

(a)

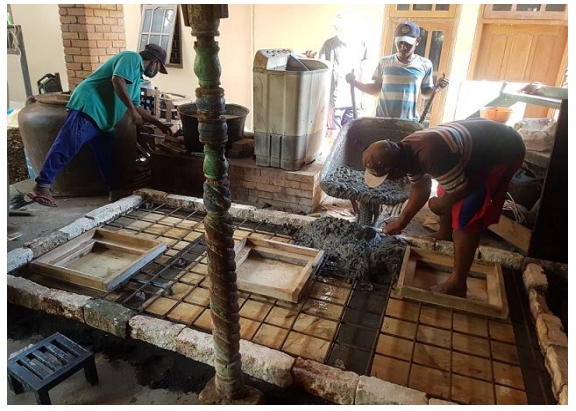

(c)

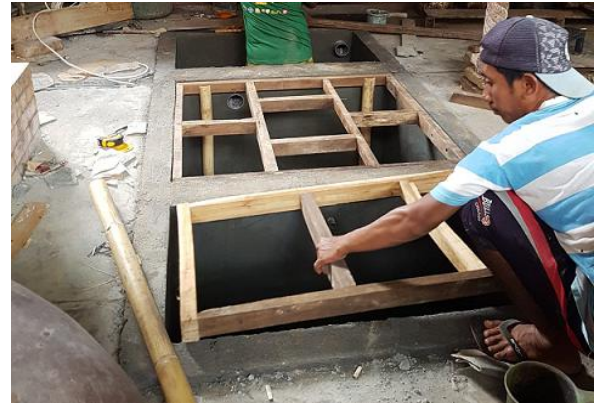

(b)

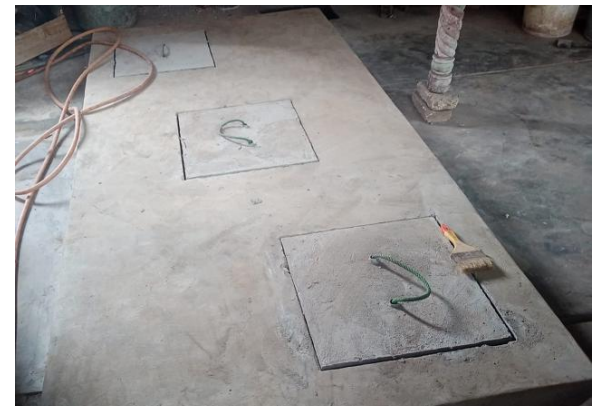

(d)

Gambar 5. Pekerjaan bak pengendap dan perata: (a) Pekerjaan pasangan bata dinding dan sekat,

(b) Pemasangan kayu beton penutup, (c) Pengecoran beton penutup, dan (d) Bangunan bak selesai

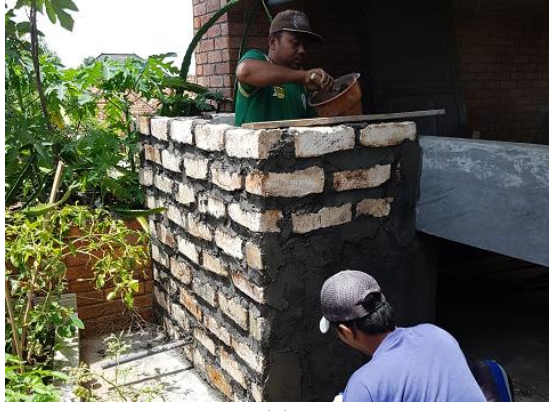

(a)

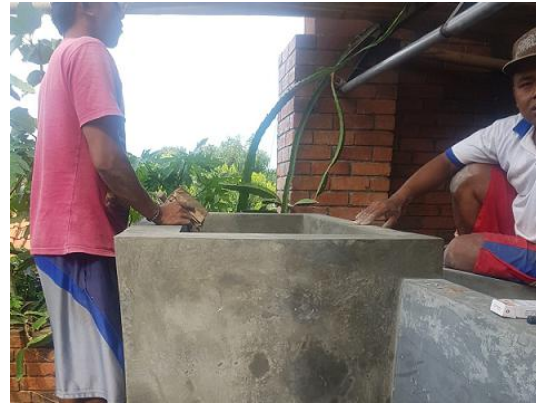

(c)
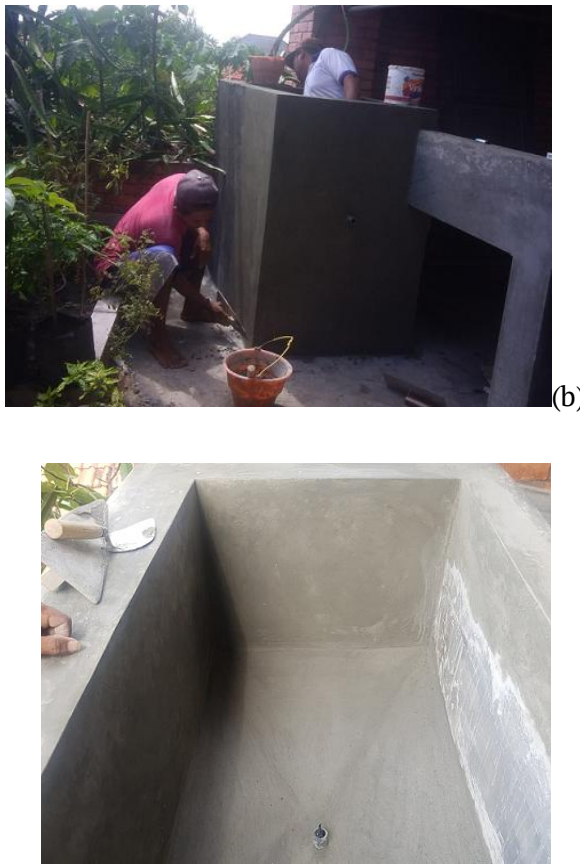

(d)

Gambar 6. Pekerjaan bangunan bak koagulasi (a) Pasangan batu bata dinding,

(b) Plester dinding, (c) Penghalusan (aci) dinding, (d) Bangunan bak selesai

Gambar 4 bagian Bak 4 dan 5 adalah bak absorbsi arang aktif berjumlah 3 buah dan sebuah bak kontrol akhir (tampak samping). Ukuran tiga bak absorbsi dan bak kontrol akhir adalah panjang total $240 \mathrm{~cm}$, lebar $130 \mathrm{~cm}$, dan dalam $130 \mathrm{~cm}$. Panjang masing-masing bak adalah sama sebesar $60 \mathrm{~cm}$. Volume total bak absorbsi adalah 3,042 $\mathrm{m}^{3}$ dan volume bak kontrol adalah $1,014 \mathrm{~m}^{3}$. Bak 4 berfungsi menyerap warna dan logam berat yang masih tersisa dalam air 
limbah. Media absorbsi padat yang digunakan adalah arang kayu atau arang batok kelapa berbentuk blok $5 \mathrm{~cm}$. Setelah melewati filter berjenjang pada tiga buah bak absorbsi selanjutnya air limbah mengalir menuju bak pamungkas yaitu bak kontrol akhir (Bak 5). Bak ini adalah air limbah terakhir yang relatif aman bagi lingkungan sebelum dibuang ke saluran selokan atau sungai. Berdasarkan hasil diskusi antara pelaksana dengan mitra, jika uji IPAL berhasil beroperasi dengan normal, mitra akan memanfaatkan ail limbah bak kontrol untuk menyiram tanaman. Indikator keamanan air buangan akhir limbah bagi lingkungan dilakukan dengan memasukkan ikan lele ke dalam bak kontrol. Gambar 7 menunjukkan tahapan pekerjaan bangunan bak absorbsi karbon aktif (Bak 4) dan bak kontrol (Bak 5).

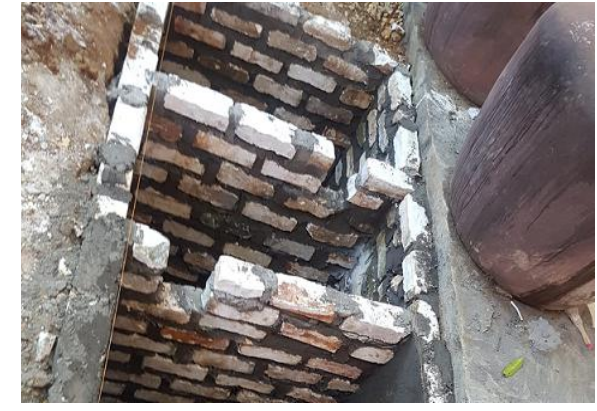

(a)

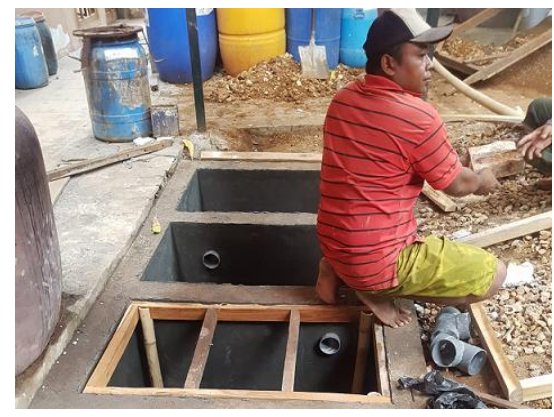

(c)

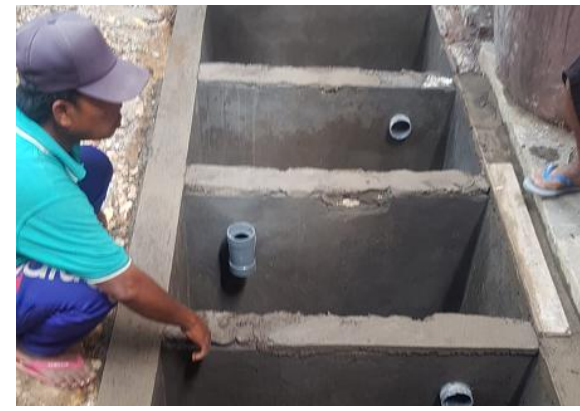

(b)

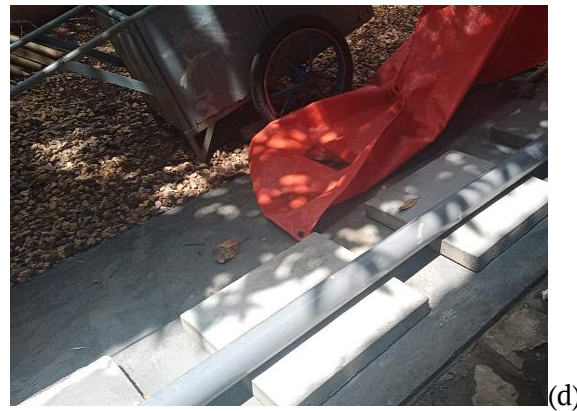

Gambar 7. Pekerjaan bangunan bak absorbsi karbon aktif dan bak kontrol akhir: (a) Pasangan batu bata dinding dan sekat, (b) Pengukuran pasangan kayu alas beton penutup, (c) Pemasangan kayu alas beton penutup, dan (d) Bangunan bak selesai

\subsection{Penerapan Teknologi Pembangkit PV}

Gambar 8 menunjukkan desain penerapan teknologi pemanfaatan energi terbarukan matahari berupa panel PV berkapasitas $900 \mathrm{Wp}$. Panel surya terdiri dari 6 buah modul PV masing-masing berkapasitas $150 \mathrm{Wp}$. Pembangkit ramah lingkungan ini berfungsi menggerakkan pompa untuk mengangkat air dari bak pengendap dan perata aliran ke bak koagulasi (Gambar 3) pada IPAL di Mitra 1. Fungsi selanjutnya Mitra 2 masih mampu melakukan aktivitas membatik walaupun pasokan listrik PLN di Desa Paseseh mengalami gangguan akibat pemadaman. Sebab kegiatan membatik membutuhkan penerangan lampu dan listrik untuk pemanas lilin yang memadai baik ketika membuat motif atau isian warna pada kain batik. Kegiatan yang dilakukan adalah inovasi dan penerapan TTG Solar Home System (SHS) menggunakan pembangkit PV skala rumah-tangga ke Mitra 1 dan 2. Desain pembangkit PV yang dipasang adalah ada dua mode. Mode pertama bersifat mandiri pada siang hari cuaca cerah, kapasitas baterai penuh, dan beban listrik sesuai dengn kapasitas PV, sehingga mampu lepas (off-grid) dengan jaringan listrik PLN 220 Volt (Ari Rahayuningtyas, et.al, 2014). Mode kedua bersifat on-grid pada siang hari cuaca mendung atau malam hari, sehingga PV tidak mampu mengisi baterai secara penuh dan sebagian energinya disuplai oleh sumber listrik PLN melalui hibrid inverter (Amirullah, et.al, 2016; Amirullah dan Agus Kiswantono, 2016). Komponen pendukung pembangkit PV meliputi Panel 
Surya 900 Wp, Baterai 100 Ah/12 V, Hibrid Inverter AC-DC-AC, 2 Stop kontak berdaya masingmasing 300 VA. Di dalam hibrid inverter ada komponen MPPT solar charge controller, inverter, dan grid. MPPT solar charge controller mengatur proses pengisian dan pelepasan energy listrik antara panel PV dan baterai. Inverter DC/AC mengkonversi tegangan DC ke tegangan AC. Grid inverter mengubah gelombang tegangan/arus AC yang masih mengandung komponen harmonisa menjadi tegangan/arus sinusoida murni.

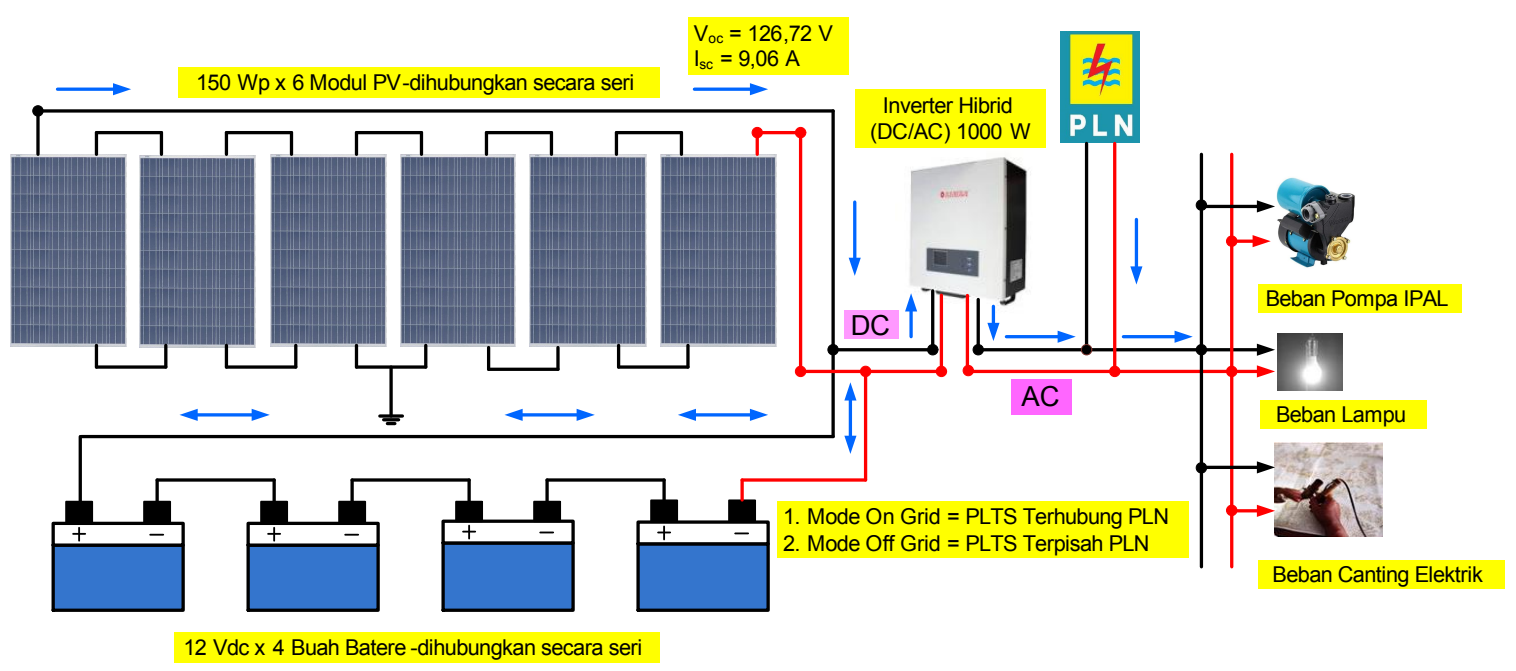

Gambar 8. Desain pembangkit PV untuk penggerak pompa IPAL batik tulis

Tahapan perencanaan sistem pembangkit PV mode off-grid untuk mendapatkan desain PV optimal sesuai kebutuhan IPAL Batik Tulis di Mitra 1 yakni: (a) Langkah pertama menentukan tegangan total dan arus total keluaran Panel PV sesuai Persamaan 1 dan 2. Panel PV $900 \mathrm{Wp}$ terdiri dari 6 modul PV masing-masing berkapasitas $150 \mathrm{Wp}$. Modul PV yang digunakan adalah Merk STC dengan tegangan hubung terbuka (VOC) sebesar 21,12 V dan arus hubung singkat (IsC) sebesar 9,06 A.

$\begin{aligned} \text { Tegangan Total Panel PV } & =J u m l a h \text { Modul PV } \times \text { Tegangan Modul PV Hubung Terbuka (Voc) } \\ & =6 \times 21,12=126,72 \mathrm{~V}\end{aligned}$

Arus Total Panel PV = Arus Modul PV Hubung Singkat (Isc) = 9,06 A

(b) Langkah kedua adalah menghitung kebutuhan energi masing-masing peralatan sesuai Persamaan 3. Pompa IPAL $200 \mathrm{~W}$ menyala selama 1 jam.

Energi Harian $=$ Daya $($ W) $\times$ Waktu $($ jam $)=200 \times 1=200$ Watt-hour $($ Wh $)$

Beban lampu $150 \mathrm{~W}$ menyala selama 6 jam membutuhkan energi $900 \mathrm{Wh}$. Beban canting elektrik $150 \mathrm{~W}$ digunakan selama 6 jam membutuhkan energi $900 \mathrm{Wh}$. Sehingga, total kebutuhan energi harian sistem PLTS adalah 2.000 Wh. Daya panel PV yang dibutuhkan sesuai Persamaan 4.

Daya Panel PVyang dibutuhkan = Energi Harian $(W h) /$ Jumlah jam efektif

$$
=(2.000) / 4=500 \mathrm{~W}
$$

Berdasarkan perhitungan tersebut maka dipilih panel PV berkapasitas $900 \mathrm{Wp}$ karena terdiri dari 6 modul PV masing-masing berkapasitas $150 \mathrm{Wp}$. Pemilihan daya PV sebesar $900 \mathrm{Wp}$ dilakukan berdasarkan pemilihan daya terpasang langganan PLN terdekat di atasnya sebesar 900 VA. (c) Langkah ketiga adalah menghitung jumlah kebutuhan baterai berdasarkan jumlah konsumsi energi harian sesuai Persamaan 5. 


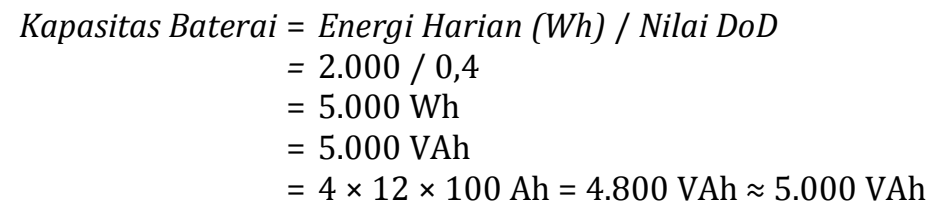

Berdasarkan perhitungan kapasitas baterai maka dibutuhkan 4 buah baterai masing-masing bertegangan $12 \mathrm{Vdc}$ dan $100 \mathrm{Ah}$. (d) Langkah keempat adalah menentukan durasi pemanfaatan pembangkit PV berdasarkan nilai investasi atau break even point (BEP) dengan prosedur sebagai berikut.

Tabel 1 Biaya komponen pembangkit PV $1.000 \mathrm{~W}$

\begin{tabular}{clcrr}
\hline No. & Komponen PLTS 1.000 W & $\begin{array}{r}\text { Jumlah Komponen } \\
\text { (unit) }\end{array}$ & $\begin{array}{r}\text { Harga per-unit } \\
\text { (Rp) }\end{array}$ & $\begin{array}{c}\text { Biaya } \\
\text { (Rp) }\end{array}$ \\
\hline 1 & Solar Panel Poly 900 W-6 Unit @ 150 Wp & 6 & 900.000 & 5.400 .000 \\
2 & Inverter Hybrid 1.000 W & 1 & 3.850 .000 & 3.850 .000 \\
3 & Baterai VRLA 12 Volt 100 Ah & 4 & 2.300 .000 & 9.200 .000 \\
4 & Box Baterai 2 Pintu & 1 & 900.000 & 900.000 \\
5 & Balancing Baterai 24 Volt & 1 & 235.000 & 235.000 \\
6 & MCB & 1 & 628.000 & 628.000 \\
7 & Kabel Power10 m & 1 & 80.000 & 80.000 \\
8 & Kabel Power 2 x 1,5 m & 1 & 415.000 & 415.000 \\
9 & Besi Persegi Panjang 4 x 6 cm tebal 1 mm & 4 & 250.000 & 1.000 .000 \\
10 & Box MCB & 1 & 130.000 & 130.000 \\
11 & Stop Kontak 2 Output & 1 & 66.000 & 66.000 \\
12 & Accecories & 1 & 100.000 & 100.000 \\
13 & Paket Instalasi, Pengujian PLTS, Selesai & 1 & 5.000 .000 & 5.000 .000 \\
14 & PPn 10\% Paket PLTS & 1 & 2.700 .400 & 2.700 .400 \\
\hline & & & Total Biaya & 29.704 .400 \\
\hline
\end{tabular}

Energi listrik yang dihasilkan dari instalasi pembangkit PV sesuai Persaman 6.

Energi Listrik Harian yang Dihasilkan = Kapasitas Panel Surya Terpasang / Jumlah Jam Efektif

$$
=900 \times 4=3.600 \mathrm{Wh} \text { per hari }=3,6 \mathrm{kWh} / \mathrm{hari}
$$

Berdasarkan tarif listrik terbaru PLN periode April-Juni 2021, tarif rumah tangga kelas daya 900 VA harganya yakni Rp1.352/kWh (Virdita Ratriani, 2021). Sehingga, tarif listrik sesuai Persamaan 7.

$$
\begin{aligned}
\text { Tarif Listrik } & =\text { Jumlah } \mathrm{kWh} / \text { hari } \times \text { Jumlah Jam Efektif } \\
& =3,6 \times \mathrm{Rp} 1.352=\mathrm{Rp} 4.868
\end{aligned}
$$

Sehingga, durasi pemanfaatan pembangkit PV berdasarkan nilai investasi atau break even point (BEP) diperoleh sesuai Persamaan 8.

$$
\begin{aligned}
\text { Waktu BEP } & =\text { Biaya Investasi PLTS / Tarif Listrik } \\
& =29.704 .400 / 4.868=6.102 \text { hari } \approx 16 \text { tahun } 8 \text { bulan }
\end{aligned}
$$

Berdasarkan analisis BEP, diperoleh bahwa instalasi pembangkit PV dapat dimanfaatkan untuk melayani beban di Mitra 1 selama 16 tahun 8 bulan. Kalkulasi tersebut dihitung dengan asumsi tidak ada pergantian komponen baterai selama waktu BEP. Jika komponen umur efektif pemakaian baterai rata-rata sebesar 5 tahun atau dilakukan penggantian baterai setiap 5 tahun sekali, maka waktu BEP akan semakin lama (Sandro Putra, 2019).

Hasil perancangan sistem pembangkit PV untuk suplai daya IPAL Batik Tulis selanjutnya disajikan pada Tabel 2. Berdasarkan Pembangkit PV yang sudah didesain pada Tabel 2, maka selanjutnya pelaksana program menunjuk kontraktor instalasi PV untuk melakukan pengadaan material dan pemasangan instalasi Pembangkit PV di Mitra 1. Ada empat pekerjaan yang sudah dilaksanakan yaitu: (1) Pekerjaan pembuatan rangka besi penyangga panel PV, (2) Pekerjaaan instalasi panel surya daya $900 \mathrm{Wp}$ pada rangka besi, (3) Pekerjaan instalasi kotak (box) besi 
baterai dan baterai PV, (4) Pekerjaan instalasi inverter hibrid $1000 \mathrm{~W}$, (5) pekerjaan pemasangan MCB dan stup kontak sistem pembnagkit PV, (6) Penyambungan instalasi sistem pembangkit PV ke beban pompa IPAL dan beban lampu penerangan, dan (7) Pengujian kinerja instalasi sistem pembangkit PV terhubung ke beban. Pekerjaan instalasi pembangkit PV mulai awal hingga selesai dilanjutkan pengujian kinerja peralatan dilakukan selama lima hari sejak $7 \mathrm{~s} / \mathrm{d} 11$ Oktober 2021 dimana tahapannya ditunjukkan pada Gambar 8.

Tabel 2. Desain Sistem Pembangkit PV

\begin{tabular}{clc}
\hline No. & \multicolumn{1}{c}{ Parameter } & Nilai Desain \\
\hline 1 & Tegangan Panel PV Hubung Terbuka (Voc) & $126,72 \mathrm{~V}$ \\
& Arus Panel PV Hubung Singkat (Isc) & $9,06 \mathrm{~A}$ \\
2 & Daya Panel PV & $900 \mathrm{Wp}$ \\
& Daya Modul PV & $150 \mathrm{Wp}$ \\
& Jumlah Modul & $6 \mathrm{Unit}$ \\
& Hubungan Rangkaian Modul PV & Seri \\
3 & Daya Inverter Hibrid & $1.000 \mathrm{~W}$ \\
4 & Jumlah Baterai & $4 \mathrm{Unit}$ \\
& Tegangan Setiap Baterai & $12 \mathrm{Vdc}$ \\
& Kapasitas Baterai & $100 \mathrm{Ah}$ \\
& Hubungan Rangkaian Baterai & Seri \\
5 & Beban Pompa IPAL Batik Tulis & $200 \mathrm{~W}$ \\
& Beban Lampu Penerangan & $150 \mathrm{~W}$ \\
& Beban Canting Batik & $150 \mathrm{~W}$ \\
6 & Waktu BEP Sistem Pembangkit PV & 16 tahun 8 bulan \\
\hline
\end{tabular}

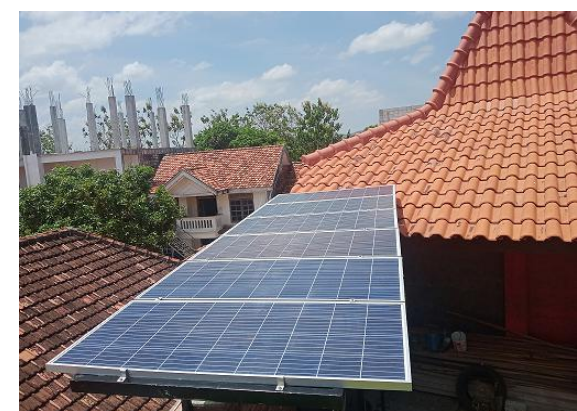

(a)

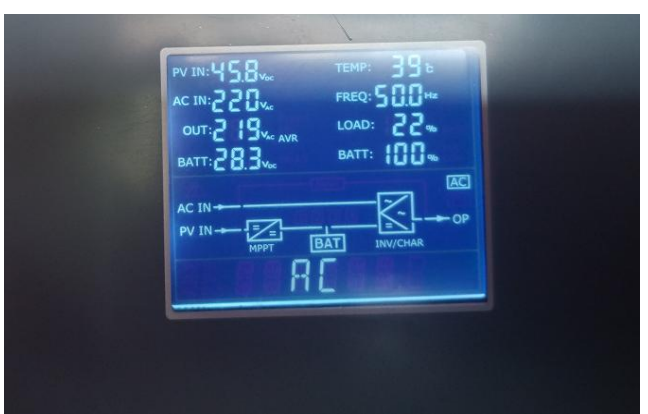

(c)

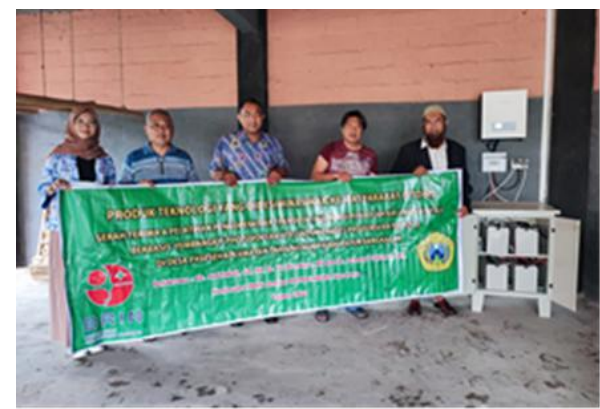

(b)

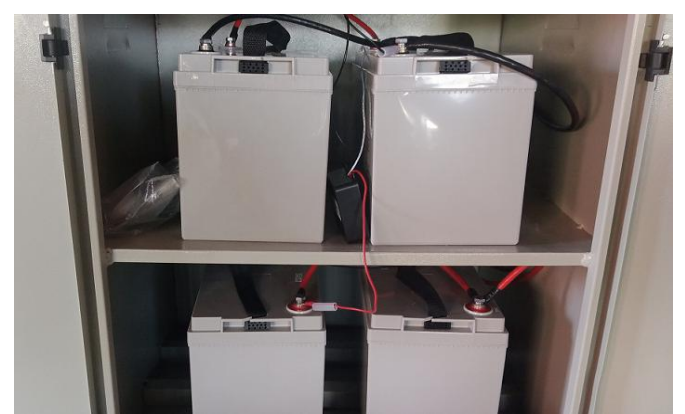

(d)

Gambar 8. Pekerjaan instalasi pembangkit PV (a) Instalasi panel PV kapasitas $900 \mathrm{Wp}$, (b) Foto bersama pelaksana, mitra, dan mahasiswa, (c) Display digital inverter inverter $1.000 \mathrm{~W}$ mode on-grid, (d) 4 Unit baterai kering masing-masing bertegangan $12 \mathrm{~V}-100 \mathrm{Ah}$

\subsection{Pengoperasian Teknologi IPAL-Pembangkit PV}

Setelah IPAL batik tulis berbasis pembangkit PV dipasang, tahap selajutnya adalah pekerjaan memasukkan arang kayu ke dalam bak absorbsi karbon aktif dan instalasi pompa di bak pengendap dan perata aliran. Untuk meningkatkan pemahaman Mitra 1 mengenai 
operasional IPAL-Pembangkit PV, Tim pelaksana melakukan pelatihan dan uji-coba pengoperasian alat pada pada Sabtu-Minggu, 20-21 Nopember 2021 dimana aktivitasnya ditunjukkan pada Gambar 9.

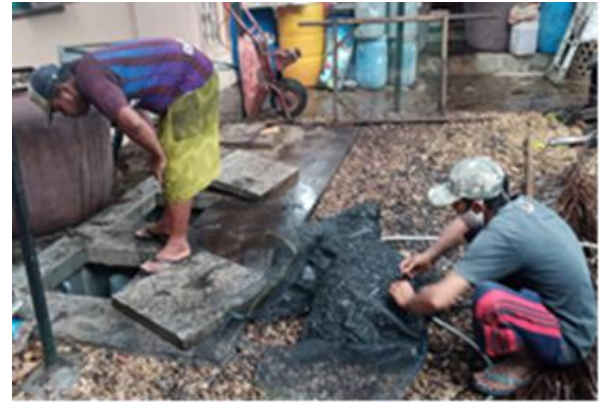

(a)

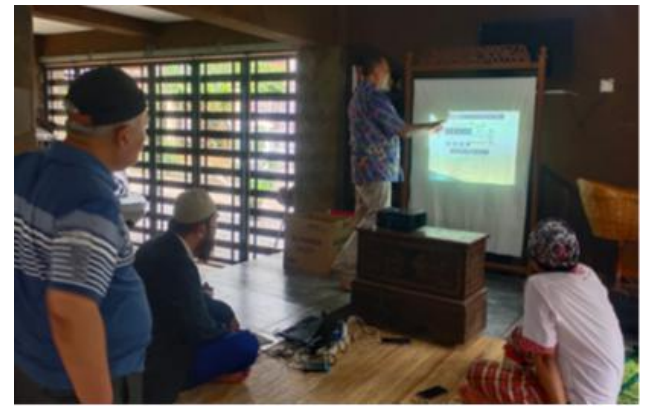

(c)

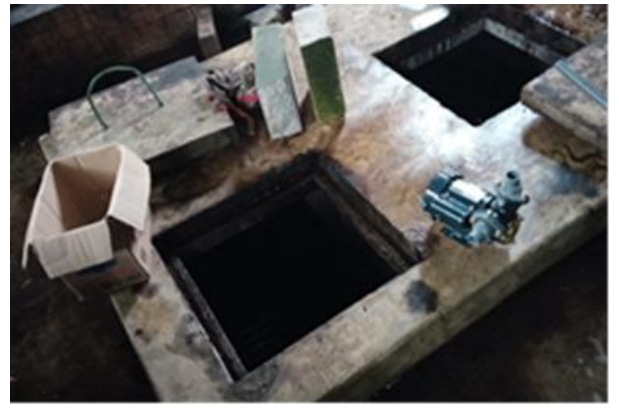

(b)

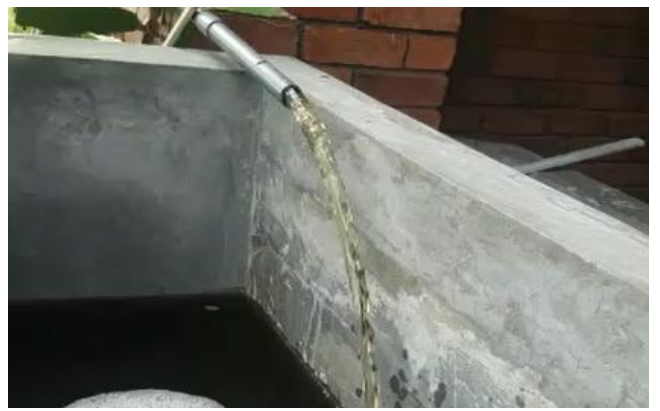

(d)

Gambar 9. (a) Pekerjaan memasukkan arang kayu ke dalam bak absorbsi, (b) Instalasi pompa di bak pengendap, (c) Pelatihan operasional IPAL-Pembangkit PV, dan (d) Uji-coba operasional alat ke Mitra 1

Indikator pemanfaatan teknologi IPAL-Pembangkit PV selanjutnya ditentukan oleh parameter kinerja sebelum dan sesudah instalasi dipasang di kedua mitra. Parameternya ditunjukkan pada Tabel 3 meliputi aspek antara-lain: kapasitas penampungan air limbah, pemanfaatan air bekas limbah, pemadaman listrik PLN, dan tagihan rekening listrik PLN.

Tabel 3 Parameter Kinerja Sebelum dan Sesudah Pemasangan IPAL-Pembangkit PV

\begin{tabular}{|c|c|c|c|}
\hline No. & Parameter Kinerja & $\begin{array}{c}\text { Sebelum Dipasang } \\
\text { IPAL-Pembangkit PV }\end{array}$ & $\begin{array}{c}\text { Sesudah Dipasang } \\
\text { IPAL-Pembangkit PV }\end{array}$ \\
\hline 1 & $\begin{array}{l}\text { Kapasitas penampungan } \\
\text { air limbah }\end{array}$ & $0 \mathrm{~m}^{3}$ & $\begin{array}{l}\text { Bak pengendap }=4,62 \mathrm{~m}^{3} \\
\text { Bak koagulasi }=1,44 \mathrm{~m}^{3} \\
\text { Bak absorbsi }=3,042 \mathrm{~m}^{3} \\
\text { Bak kontrol }=1,014 \mathrm{~m}^{3} \\
\text { Total }=10,116 \mathrm{~m}^{3}\end{array}$ \\
\hline 2 & $\begin{array}{l}\text { Pemanfaatan air bekas } \\
\text { limbah }\end{array}$ & $\begin{array}{l}\text { Tidak dapat dimanfaatkan karena } \\
\text { dibuang langsung ke sungai atau } \\
\text { selokan }\end{array}$ & $\begin{array}{l}\text { Digunakan kembali untuk } \\
\text { pelorodan/pencucian kain batik dan } \\
\text { menyiram tanaman. }\end{array}$ \\
\hline 3 & Pemadaman listrik PLN & $\begin{array}{l}\text { Lampu di Mitra } 1 \text { padam dan Mitra } 2 \\
\text { tidak dapat melakukan aktivitas } \\
\text { membatik. }\end{array}$ & $\begin{array}{l}\text { Pompa IPAL mampu beroperasi } \\
\text { normal, lampu di Mitra } 1 \text { menyala, } \\
\text { dan Mitra } 2 \text { mampu melakukan } \\
\text { aktivitas membatik. }\end{array}$ \\
\hline 4 & $\begin{array}{l}\text { Tagihan rekening listrik } \\
\text { PLN dengan daya } 900 \mathrm{~W}\end{array}$ & Rp300.000 per-bulan & Rp150.000 per-bulan \\
\hline
\end{tabular}




\section{Kesimpulan}

IPAL batik-tulis berbasis pembangkit PV untuk proses produksi batik-tulis Tanjung Bumi yang ramah lingkungan sudah didesain dan diimplementasikan di Mitra 1 dan 2. Bangunan IPAL terdiri dari bak penangkap lilin, bak pengendap dan perata aliran berjumlah tiga buah, bak koagulasi berisi filter tawas, bak absorbsi karbon aktif berisi filter arang kayu atau batok kelapa berjumlah tiga buah, dan bak kontrol akhir. Bak kontrol akhir berfungsi menampung air limbah terakhir yang relatif aman bagi lingkungan sebelum dibuang ke saluran selokan atau sungai. Air limbah juga dapat dimanfaatkan untuk proses pencucian batik kembali atau dipakai untuk menyiram tanaman. Sistem pembangkit PV dengan daya panel $900 \mathrm{Wp}$, baterai $12 \mathrm{~V} / 100 \mathrm{Ah}$, dan inverter hybrid $1.000 \mathrm{~W}$ dipakai menggerakkan pompa $200 \mathrm{~W}$ untuk mengangkat air limbah dari bak pengendap dan perata aliran ke bak koagulasi. Sumber listrik berbasis energi terbarukan ini juga digunakan untuk lampu penerangan $150 \mathrm{~W}$ dan sumber daya canting batik elektrik $150 \mathrm{~W}$ bagi Mitra 1 dan 2 baik pada mode off-grid maupun on-grid.

\section{Ucapan Terima Kasih}

Program Produk Teknologi yang Didesiminasikan ke Masyarakat (PTDM) berjudul Teknologi Instalasi Pengolah Air Limbah (IPAL) Berbasis Pembangkit Photovoltaic (PV) untuk Proses Produksi Batik Tulis Tanjung Bumi yang Ramah Lingkungan di Desa Paseseh Kecamatan Tanjung Bumi Kabupaten Bangkalan Jawa-Timur dibiayai oleh Direktorat Riset dan Pengabdian Masyarakat Deputi Bidang Penguatan Riset dan Pengembangan Badan Riset dan Inovasi Nasional sesuai dengan Kontrak Pelaksanaan Program Produk Teknologi yang Didiseminasikan ke Masyarakat Nomor: 022/SP2H/DPTM/DRPM/2021, tanggal 29 Juli 2021.

\section{Daftar Pustaka}

Abdul Hoyyi, Sugito, Hasbi Yasin, (2018), Sosialisasi Pengelolaan Limbah Industri Batik pada Program IbPUD Kerajinan Batik Bakaran di Kabupaten Pati Jawa Tengah, E-DIMAS: Jurnal Pengabdian kepada Masyarakat, 9(2), 158-166, 2018, DOI: 10.26877/e-dimas.v9i2.1785.

Amirullah, Ontoseno Penangsang, and Adi Soeprijanto, Power Quality Analysis of Integration Photovoltaic Generator to Three Phase Grid under Variable Solar Irradiance Level, TELKOMNIKA, Vol.14, No. 1, pp. 29-38, March 2016, DOI: 10.12928/telkomnika.v14i1.3298.

Amirullah and Agus Kiswantono, (2016) Power Quality Enhancement of Integration Photovoltaic Generator to Grid under Variable Solar Irradiance Level using MPPT-Fuzzy, International Journal of Electrical and Computer Engineering (IJECE),Vol. 6, No. 6, pp. 2629-2642, December 2016, DOI: 10.11591/ijece.v6i6.pp2629-2642.

Anonim (2018), Listrik Sering Padam, Warga Arosbaya Resah, Diambil 4 Maret 2018 dari advokasi.co, Link: https://advokasi.co/listrik-sering-padam-warga-arosbaya-resah.

Ari Rahayuningtyas, Seri Intan Kuala, dan Ign. Fajar Apriyanto Ari, (2014), Studi Perencanaan Sistem Pembangkit Listrik Tenaga Listrik (PLTS) Skala Rumah Tangga Sederhana di Daerah Pedesaan sebagai Pembangkit Listrik Alternatif untuk Mendukung Program Ramah Lingkungan dan Energi Terbarukan, Prosiding SNaPP2014 Sains, Teknologi, dan Kesehatan ISSN 2089-3582, EISSN 2303-2480, Pusat Pengembangan Teknologi Tepat Guna, LIPI, Link http://proceeding.unisba.ac.id/index.php/sains_teknologi/article/view/592.

Azhar Kamal, (2017), Materi Workshop Green Energy: Pemilihan Instalasi dan Sistem Kontrol Roof Top Solar Panel, 20 Oktober 2017, Politeknik Negeri Malang.

http://radarmadura.co.id/2015/03/melihat-dari-dekat-pewarnaan-batik-gentongan-tanjungbumi/. 
Lilin Indrayani, (2019), Teknologi Pengolahan Limbah Cair Batik dengan IPAL BBKB Sebagai Salah Satu Alternatif Percontohan bagi Industri Batik, Seminar Nasional Teknik Kimia KejuanganPengembangan Teknologi Kimia untuk Pengolahan Sumber Daya Alam Indonesia, Yogyakarta, 25 April 2019, Hal. H8-1 s/d H8-9, ISSN 1693-4393. Link: http://jurnal.upnyk.ac.id/index.php/kejuangan/article/view/2847.

Rafael Sianipar, (2014), Dasar Perencanaan Pembangkit Listrik Tenaga Surya, JETri: Jurnal Ilmiah Teknik Elektro, Volume 11, Nomor 2, Februari 2014, Hal. 61-78, DOI: 10.25105/jetri.v11i2 .1445.

Sandro Putra dan Ch. Rangkuti, (2016), Perencanaan Pembangkit Listrik Tenaga Surya Secara Mandiri Untuk Rumah Tinggal, Proseding Seminar Nasional Cendekiawan 2016, Hal. 23.123.7, Link: PROSIDING SEMINAR NASIONAL CENDEKIAWAN, https://www.trijurnal.lemlit .trisakti.ac.id.

Virdita Ratriani, (2021) Cek, daftar tarif listrik PLN terbaru periode April-Juni 2021, Diambil 5 April, 2021 dari kontan.co.id, Link: https://industri.kontan.co.id/news/cek-daftar-tariflistrik-pln-terbaru-periode-april-juni-2021. 


\section{Afiliasi:}

Amirullah*, Anis Fitriani, Uais Sabilah Muhammad

Teknik Elektro, Fakultas Teknik, Universitas Bhayangkara Surabaya

Jalan Ahmad Yani 114, Surabaya, Jawa Timur

Email: amirullah@ubhara.ac.id*, anisfitriani213@gmail.com, uaissabilah33@gmail.com

Tri Wardoyo, Achmad Yulianto

Teknik Sipil, Fakultas Teknik, Universitas Bhayangkara Surabaya

Jalan Ahmad Yani 114, Surabaya, Jawa Timur

Email: triwardoyo_ubhara@yahoo.co.id,ayuli4nt@gmail.com 